Int. J. Dev. Biol. 58: 723-725 (2014)

doi: $10.1387 / \mathrm{ijdb} .150111 \mathrm{jg}$

\title{
A view of amphibian embryology during the last century
}

\author{
JOHN B. GURDON* \\ Wellcome Trust/Cancer Research UK University of Cambridge, Cambridge, UK
}

\begin{abstract}
Having started working in the field of amphibian embryology over 50 years ago, I make some comments about the changes that seem to me to have taken place in this field over this period. Over the period 1885 to 1960 , much of the highly regarded experimental embryology was conducted on amphibian eggs and embryos. Indeed, much of this work was conducted in Germany and Switzerland using eggs and embryos of European newts (salamanders) and frogs of the Rana group. Xenopus started to be used extensively after the 1950s because eggs and embryos could be obtained throughout the year by hormone injection and because sexually mature animals could be raised from an egg within one year. Since the 1960s, publications using Xenopus have exceeded those using other amphibian species by 100 -fold. This short commentary highlights some of the major advances attributable to embryological work with Amphibia and exemplifies these advances by reference to those who have made conspicuous contributions in this area.
\end{abstract}

KEY WORDS: Amphibian, history, Spemann, Hamburger, Brachet, Gurdon

Having started working in the field of amphibian embryology over 50 years ago, I may be in a better position than some others to look back at the changes that have taken place during this time. When I started my PhD work in 1956, I was offered a project involving amphibian embryos. The historical background to working in this field has, since then, been brilliantly summarized by Hamburger (1988). He points out that experimental embryology had held a commanding position in the field of biology during the first half of the 1900s. This book is both fascinating from a historical point of view but is also extremely readable, and its merit is further enhanced by the inclusion of anecdotes from Hamburger's own life experience. He says: "At the time of Spemann, scientists were impressed by the superb craftsmanship in the performance of the masters of their art, which consisted essentially of extirpation, transplantation, and explantation (in tissue culture). Spemann's organizer experiment (Spemann and Mangold, 1924) was widely regarded as the crowning achievement of that period".

Von Baer (1828) is seen as having initiated scientific embryology, and Roux (1885) as the earliest of the true experimental embryologists. Thus the field of embryology could be seen to have originated largely in Germany and Switzerland and to have made predominant use of amphibian embryos which were large enough for skilful hand manipulation and relatively easily obtainable. The German- and Swiss-centric activity in this field followed a highly influential lineage. Thus, Boveri was the mentor of Spemann who himself was a mentor of Holtfreter, Hamburger, and Baltzer. Hadorn was a student of Baltzer and my own mentor M. Fischberg was a student of Hadorn. Fischberg (Elsdale et al., 1958), educated in Switzerland, was given a job by Waddington in Edinburgh from where he moved to a Faculty position in Oxford where I was a student of his. My own student and colleague R. A. Laskey (Laskey et al., 1989) was a supervisor to Harland and hence to a wide range of other prominent embryologists. Derivatives of this lineage included De Robertis (De Robertis and Kuroda, 2004), and many others who have made prominent contributions to developmental biology using amphibian material.

There were of course others who made major contributions to amphibian embryology apart from those on the Boveri-Spemann lineage. Prominent among these is Jean Brachet based in Brussels and son of another well-known embryologist A. Brachet. Jean Brachet (1957) is famous for his discovery that there is a close relationship between the RNAcontent of a cell and protein synthesis, thereby initiating the concept of messenger RNA. Jean Brachet was extraordinarily helpful to others unconnected with him or his lab and I was personally a major beneficiary of his advice and help. Belgium had been a stronghold of embryology when Dalcq and Pasteels had been working also in Brussels (see Brachet, 1957). In Holland, P. D. Nieuwkoop was a major contributor to embryology; he discovered what we now call the Nieuwkoop centre (Nieuwkoop, 1977), namely the first major source of signalling from endoderm

\footnotetext{
*Address correspondence to: John B. Gurdon. WellcomeTrust/Cancer Research UK University of Cambridge, Tennis Court Road, Cambridge CB2 10N, UK. e-mail: j.gurdon@gurdon.cam.ac.uk - web: http://www.gurdon.cam.ac.uk/research/gurdon
}

Accepted: 15 December 2014

ISSN: Online 1696-3547, Print 0214-6282

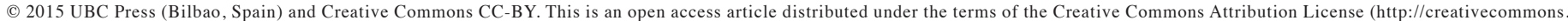

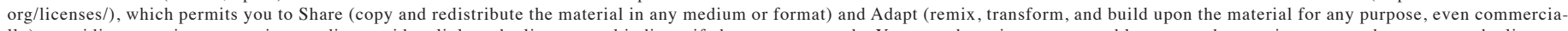

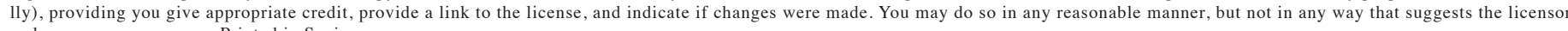
endorses you or your use. Printed in Spain 
cells to ectoderm cells of the early amphibian embryo so as to create the mesoderm. The Nieuwkoop and Faber (1956) normal table of Xenopus has been of major benefit to those working in this field. The Nieuwkoop centre precedes the Spemann centre by a few hours in amphibian development. The history of how Xenopus, a native of South Africa, came to be one of the most widely used organisms for research in development, cell and molecular biology is an interesting and curious story (Gurdon and Hopwood, 2000).

At about the time of my own graduate work, D. D. Brown (2004), working in Baltimore, took a major step forward in concentrating on nucleic acid molecules. Up till that time, biochemists including Joseph Needham, Cambridge, (1942) had concentrated on metabolic activities such as phosphorylation; he wrote two enormous volumes on early development entitled Biochemistry of Morphogenesis. Though he must have compiled almost every known fact about development, this did not lead to advances in our understanding of how development actually worked. Brown, on the other hand, was the first to make careful biochemical analyses of early development from the point of view of nucleic acids. In the 1950s there was no possibility of recognizing individual genes, either as DNAor RNA. He therefore worked with ribosomal RNA and transfer RNA as individual, though multiple copy, single types of gene. Birnstiel (Edinburgh) (Birnstiel et al., 1966) and then Brown were the first to isolate the DNA of a single kind of gene, but it took some years before this was realistic using molecular cloning methods. Also in the 1950s Briggs and King (Philadelphia) (1952) were the first to successfully transplant a living nucleus from an embryo to an enucleated egg. It was during this time that the predominance of German and Swiss embryology using amphibia gave way to oth-

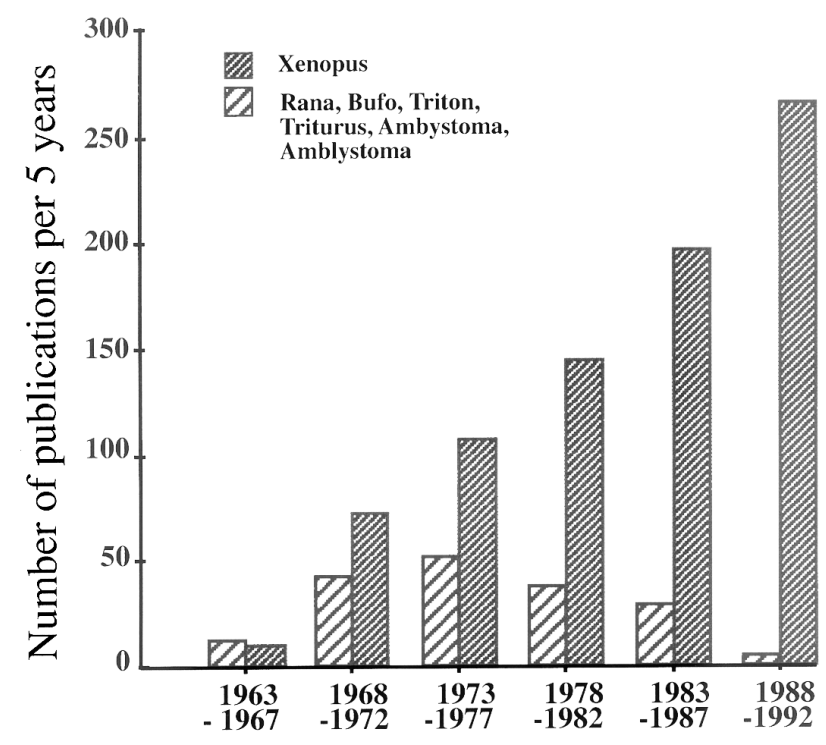

Fig. 1.A graph showing the dramatic increase in publications on Xenopus, compared to those using other Amphibian species, from about 1970. Data were retrieved from Advanced Medline Search by scoring those titles in Journal of Embryology and Experimental Morphology (subsequently Development) and Developmental Biology that include Xenopus or (for other Amphibia) Rana, Bufo, Triturus (Triton), orAmblystoma (Ambystoma). Gurdon and Hopwood (2000). Int J Dev Biol 44: 43-50. ers. As molecular methods advanced, the combination of these with abundant material at all times of year in Xenopus attracted researchers from other fields, notably J. Gerhart (Gerhart et al., 1981) and M. Kirschner (Gard and Kirschner, 1987) who had both been trained in enzymology using aspartate transcarbamylase moved to Xenopus. J. Gerhart (Berkeley) made the first full analysis of cortical rotation, the earliest post-fertilization event that leads to a dorso-ventral axis of symmetry. M. Kirschner (San Francisco) made major advances in understanding the cell cycle particularly through the use of cell-free extracts. The use of cell-free extracts was immensely valuable for short-term events such as post-fertilization DNA replication, as demonstrated particularly clearly in the hands of my colleague R. A. Laskey and his students including J. Blow (Dundee) (Blow and Laskey, 1986) and M. Mechali (France)(2010). From the 1950s onwards, the advantages of Xenopus with its hormone-inducible egg production throughout the year (contrast two months in the year for Rana species), its relatively short life cycle leading to the use of mutants such as the one-nucleolus mutant (Elsdale and Fischberg, 1958), and abundant material suitable for molecular biology largely displaced the use of other amphibia that do not respond to mammalian hormone including Rana, Triturus, Pleurodeles, etc. (see Fig. 1, graph). These advantages attracted others from a biochemical background. Notable among these is $\mathrm{E}$. de Robertis who has, more than others identified key genes and signal factors that account for early gastrulation and the Spemann organizer.

In the course of time, the development of fish (eventually zebrafish) and nematodes (Caenorhabditis) had enormous appeal to those with a background in genetics. Advances in amphibian embryology and notably that of Amaya for transgenesis (Amaya and Kroll, 1999), have kept pace with other advances. In more recent times huge advances in molecular methods enabling workers to study individual gene action have been quickly taken up by the amphibian community even when limited amounts of material, such as in nuclear transfer experiments, are available. It is still an advantage to be able, with amphibian embryos, to isolate cells of individual types from early embryos in a way that is difficult with species whose embryos are an order of magnitude or more smaller.

Finally, I may comment on personal experience in amphibian embryology. Primarily, nuclear transfer in Xenopus worked much better than could reasonably have been expected. I was particularly gratified by the success of messenger RNA injection to Xenopus embryos, an advance facilitated by Jean Brachet and made possible by messenger RNA isolation by Chantrenne (Brussels), a colleague of J. Brachet. I would lastly mention morphogen gradients as a fundamental mechanism of development. A huge advance in this field was made by J. Green and J. C. Smith (1990) following the identification of activin as an embryonic inducer. It has always been, and still is, my aim to work with single purified components, whether a single type of cell, a single type of molecule, a single type of gene, or a single type of protein. This reductionist approach worked very well in attempts to understand the molecular basis of morphogen gradient interpretation (Dyson and Gurdon, 1998). At an early stage in my career I was much influenced by some outstanding books on embryology, and strongly recommend Brachet (1957), Hamburger (1988), Saxen and Toivonen (1962) and Okada (1991). 


\section{References}

AMAYA E and KROLL KL (1999). A method for generating transgenic frog embryos. Methods Mol Biol 97: 393-414.

VON BAER CE (1828). Ueber Entwicklungsgeschichte der Thiere, Beobachtung und Reflexion, Gebrüder Bornträger, Königsberg. Reprinted 1967, Culture et Civilisation, Brussels.

BIRNSTIEL ML, WALLACE H, SIRLIN JL and FISCHBERG M (1966). Localization of the ribosomal DNA complements in the nucleolar organizer region of Xenopus laevis. Natl Cancer Inst Monogr 23: 431-447.

BLOW JJ, LASKEY RA (1986). Initiation of DNA replication in nuclei and purified DNA by a cell-free extract of Xenopus eggs. Cell 47: 577-587.

BRACHET J (1957). Biochemical Cytology. New York: Academic. 516pp.

BRIGGS R \& KING TJ (1952). Transplantation of living nuclei from blastula cells into enucleated frogs' eggs. Proc Nat Acad Sci. USA 38: 455-463.

BROWN DD (2004). A tribute to Xenopus laevis oocyte and egg. J Biol Chem 279: 45291-45299.

DAVIDSON, E.H. (1986). Gene activity in early development. Academic Press, New York.

DE ROBERTIS, EM and KURODA H (2004). Dorsal-ventral patterning and neural induction in Xenopus embryos. Annu Rev Cell Dev Biol 20: 285-308.

DYSON, S. and GURDON, J.B. (1998). The interpretation of position in a morphogen gradient as revealed by occupancy of activin receptors. Cell 93: 557-568.

ELSDALE TR, FISCHBERG M, SMITH S (1958). A mutation that reduces nucleolar number in Xenopus laevis. Exp Cell Res 14: 642-643.

GARD DL and KIRSCHNERMW (1987). Microtubule assembly in cytoplasmic extracts of Xenopus oocytes and eggs. J Cell Biol 105: 2191-201.

GERHART J, UBBELS G, BLACK S, HARAK, KIRSCHNER M. (1981). A reinvestigation of the role of the grey crescent in axis formation in Xenopus laevis. Nature 292: $511-516$
GURDON, J.B. and HOPWOOD, N. (2000). The introduction of Xenopus laevis into developmental biology: Of empire, pregnancy testing and ribosomal genes. Int J Dev Biol 44: 43-50.

GREEN JB, SMITH JC (1990). Graded changes in dose of a Xenopus activin A homologue elicit stepwise transitions in embryonic cell fate. Nature 347: 391-394.

HAMBURGER V (1988). The Heritage of experimental embryology: Hans Spemann and the Organizer. Oxford University Press.

LASKEY RA, FAIRMAN MP, BLOW JJ (1989). S phase of the cell cycle. Science 246: 609-614.

MECHALI M (2010). Eukaryotic DNA replication origins: many choices for appropriate answers. Nat Rev Mol Cell Biol 11: 728-738.

NEEDHAM J (1942). Biochemistry and Morphogenesis, Vols 1-3, Cambridge, UK: Cambridge Univ. Press 2021pp.

NIEUWKOOP PD, FABER J (1956). Normal Table of Xenopus laevis (Daudin) North-Holland, Amsterdam.

NIEUWKOOP PD (1977). Origin and establishment of embryonic polar axes in amphibian development. Curr Top Dev Biol 11: 115-132.

OKADA TS (1991). Transdifferentiation: Flexibility in Cell Differentiation. Oxford, UK: Oxford Univ. Press 238pp.

ROUX, W. (1885). Einleitung zu den Beiträgen zur Entwicklungsmechanik des Embryo. Z Biol 21: 411-428.

SAXÉN L and TOIVONEN S (1962). Primary Embryonic Induction. Logos Press, London.

SPEMANN H and MANGOLD H (1924). Uber Induktion von Embryonalanlagen durch Implantation artfremder Organisatoren. Roux' Arch F Entw mech 100: 599-638.

SPEMANN H and MANGOLD H (1924). See also: Induction of embryonic primordia by implantation of organizers from a different species. (1923). Int. J. Dev. Biol. 45: 13 - 38 (2001)

SMITH JC, PRICE BMJ, VAN NIMMEN K, HUYLEBROECK D (1990). Identification of a potent Xenopus mesoderm-inducing factor as a homolog of activin A. Nature 345: 729-731. 


\section{Further Related Reading, published previously in the Int. J. Dev. Biol.}

Sexual dimorphism of AMH, DMRT1 and RSPO1 localization in the developing gonads of six anuran species

Rafal P. Piprek, Anna Pecio, Katarzyna Laskowska-Kaszub,Jacek Z. Kubiak and Jacek M. Szymura

Int. J. Dev. Biol. (2013) 57: 891-895

Dual embryonic origin of the hyobranchial apparatus in the Mexican axolotl (Ambystoma mexicanum)

Asya Davidian and Yegor Malashichev

Int. J. Dev. Biol. (2013) 57: 821-828

Clonal analyses in the anterior pre-placodal region: implications for the early lineage bias of placodal progenitors

Sujata Bhattacharyya and Marianne E. Bronner

Int. J. Dev. Biol. (2013) 57: 753-757

Amphibian interorder nuclear transfer embryos reveal conserved embryonic gene transcription, but deficient DNA replication or chromosome segregation

Patrick Narbonne and John B. Gurdon

Int. J. Dev. Biol. (2012) 56: 975-986

Origins of $\mathrm{Cdx} 1$ regulatory elements suggest roles in vertebrate evolution

Stephen J. Gaunt and Yu-Lee Paul

Int. J. Dev. Biol. (2011) 55: 93-98

Reptile scale paradigm: Evo-Devo, pattern formation and regeneration

Cheng Chang, Ping Wu, Ruth E. Baker, Philip K. Maini, Lorenzo Alibardi and Cheng-Ming Chuong

Int. J. Dev. Biol. (2009) 53: 813-826

Proteomics analysis of regenerating amphibian limbs: changes during the onset of regeneration

Michael W. King, Anton W. Neff and Anthony L. Mescher

Int. J. Dev. Biol. (2009) 53: 955-969

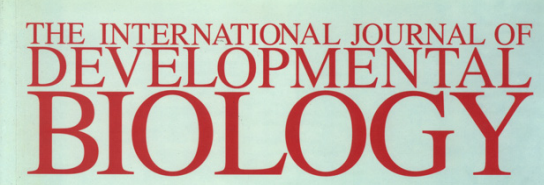

Volume 40 No. 4 August 1996

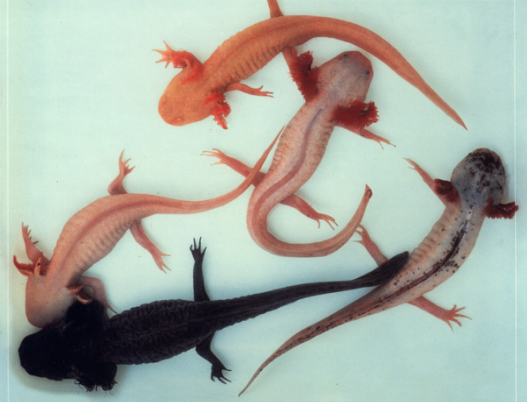

Developmental Biology of Urodeles
5 yr ISI Impact Factor $(2013)=2.879$

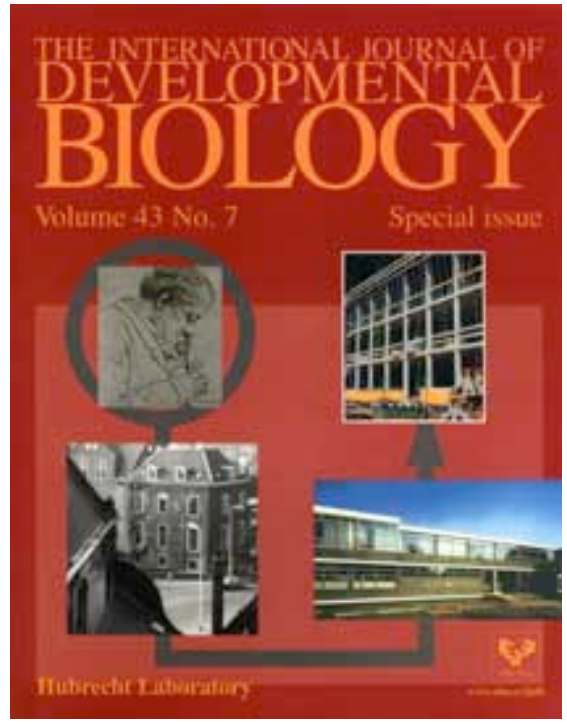

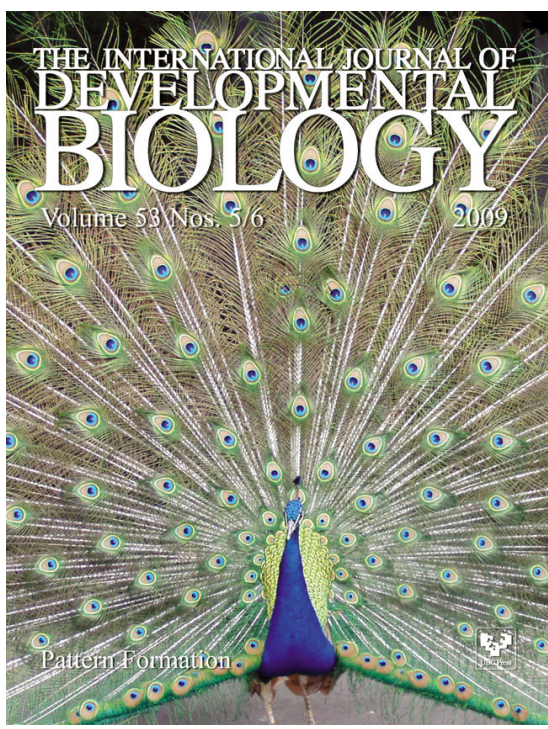
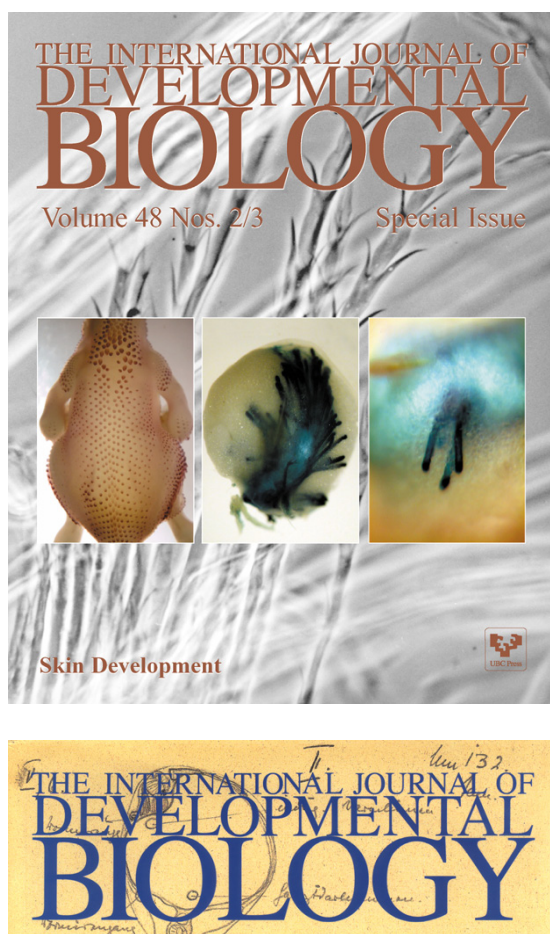

Volume 45 No. 1

Special issue
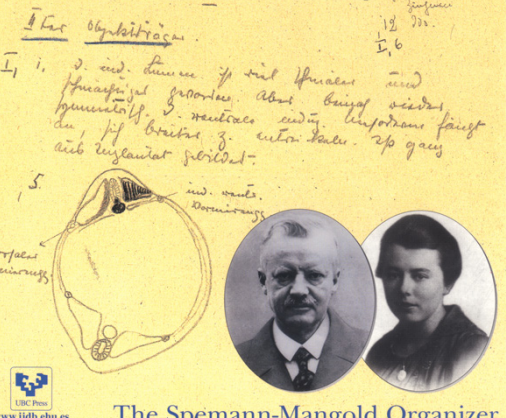

The Spemann-Mangold Organizer 